\title{
The ultrastructure of hepatocytes in alpha-1-antitrypsin deficiency with the genotype $\mathrm{Pi}_{-}$-
}

\author{
G. FELDMANN 1 , J.-P. MARTIN, R. SESBOUE, C. ROPARTZ, R. PERELMAN, \\ M. NATHANSON, P. SERINGE, AND J.-P. BENHAMOU
}

From Unité de Recherches de Physiopathologie Hépatique (INSERM), Hôpital Beaujon, Clichy, France, Centre Régional de Transfusion Sanguine and Groupe de Recherches sur la Génétique des Protéines Humaines (INSERM), Bois-Guillaume, France, and Hôpital Necker, Paris, France

SUMMARY The ultrastructural appearance of the endoplasmic reticulum of the hepatocytes was found to be normal in a 5-year-old girl with alpha-1-antitrypsin deficiency with the genotype $\mathrm{Pi}_{-}$. . The liver ultrastructure of this variant is therefore different from that of alpha-1-antitrypsin deficiency with the genotype PiZZ in which aggregates of an abnormal, unsecreted alpha-1-antitrypsin accumulate in the endoplasmic reticulum of the hepatocytes. The normal appearance of the endoplasmic reticulum in alpha-1-antitrypsin deficiency with the genotype $\mathrm{Pi}_{-}$is compatible with the hypothesis that, in this variant, synthesis of alpha-1-antitrypsin is completely, or nearly completely, absent; an alternative hypothesis would be that an abnormal alpha-1-antitrypsin is produced by the liver and secreted into the plasma, but disappears rapidly from the plasma.

Alpha-1-antitrypsin (AAT) is a sialo-protein (Schultze, Heide, and Haupt, 1962) synthesized by the hepatocytes and secreted into plasma (Scrultze and Heremans, 1966). The common variant of AAT deficiency corresponds to the homozygous genotype PiZZ and is characterized by a low serum AAT concentration (Feldmann, Bignon, and Chahinian, 1974); the mechanism for this low serum concentration is not a decrease in synthesis of the normal protein but the production of an asialo-AAT (Ericksson and Larsson, 1975) which is not normally secreted into the plasma and accumulates in the endoplasmic reticulum of the hepatocytes (Feldmann, Bignon, Chahinian, Degott, and Benhamou, 1974); the lumina of this organelle are markedly dilated and contain aggregates of the unsecreted protein (fig 1).

Another variant of AAT deficiency, very uncommon since only one patient with this disorder has been hitherto reported, has been described by Talamo, Langley, Reed, and Makino (1973); this variant is characterized by a null serum AAT concentration and corresponds to the homozygous genotype $\mathrm{Pi}_{-}$, ie, a double dose of a silent allele; the mechanism for this null serum concentration

${ }^{1}$ Please address requests for reprints to: Dr Gérard Feldmann, Unité de Recherches de Physiopathologie Hépatique, Hôpital Beaujon, 92110 Clichy, France.

Received for publication 1 July 1975 would be not the production of an abnormal protein but the absence of synthesis of normal AAT (Talamo et al, 1973). If this hypothesis is correct, it can be predicted that the AAT aggregates in the endoplasmic reticulum lumina, which are characteristic of AAT deficiency with the genotype PiZZ, should be absent in AAT deficiency with the genotype $\mathrm{Pi}_{-\ldots}$. The aim of this paper is to present the results of an ultrastructural study of the hepatocytes in a patient with AAT deficiency with the genotype

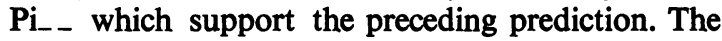
patient reported was also suffering from another hereditary disorder, mannosidosis.

\section{Patient and Methods}

The patient, a 5-year-old girl, was the only daughter of Portuguese parents who were first cousins. Mannosidosis was suspected because of a coarse face, mental retardation and vacuolized blood lymphocytes; the diagnosis was confirmed by a marked decrease in leucocyte and liver tissue alpha-mannosidase; the detailed clinical and biochemical findings in this patient have been published elsewhere (Perelman, Nathanson, Lepastier, Lesavre, Plainfosse, Chirazi, and Seringe, 1975). Deficiency of AAT was suspected because of a marked decrease in alpha-1-globulins on serum protein electrophoresis; the lungs were clinically and 


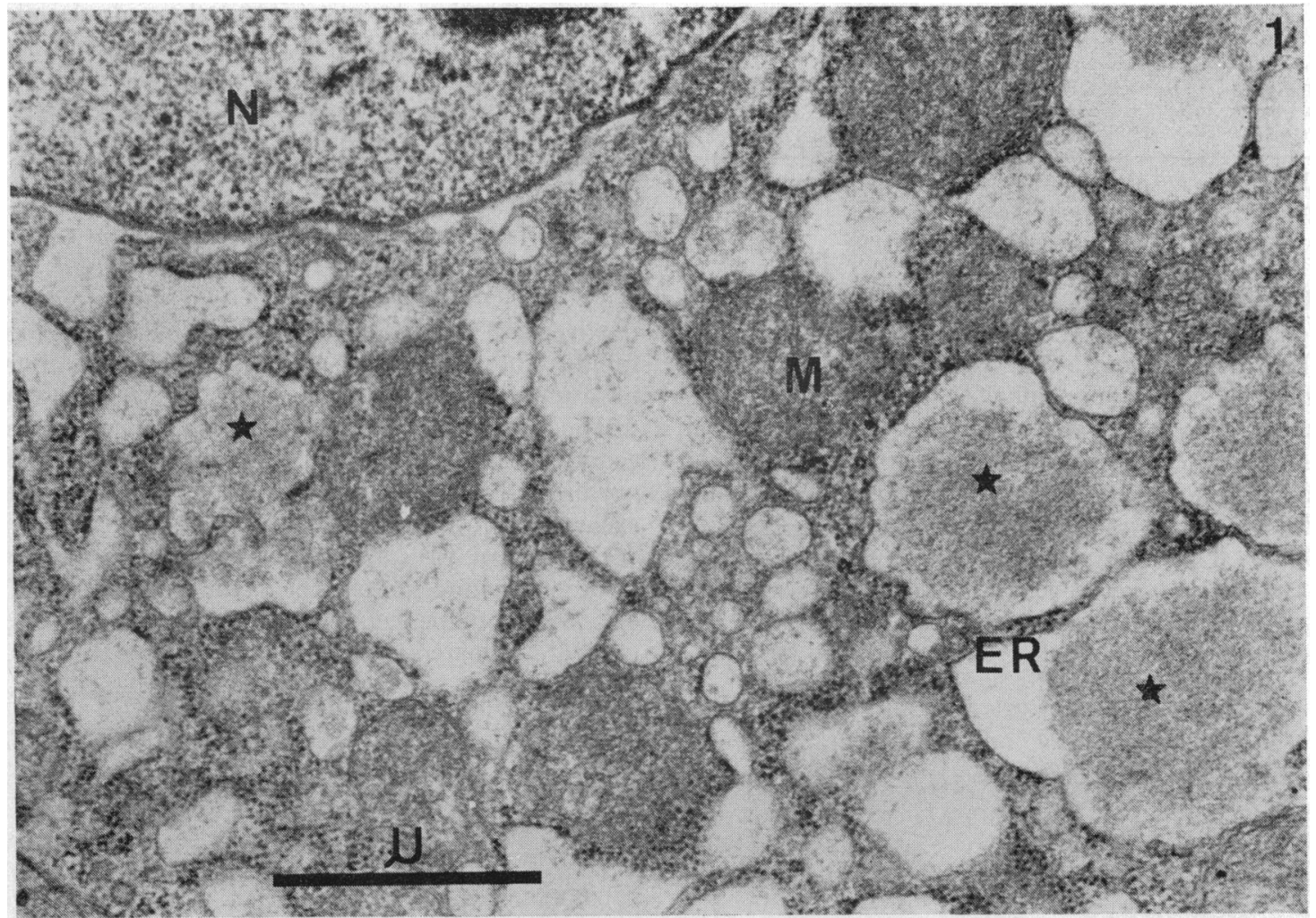

Fig 1 Electron microscope appearance of a part of a hepatocyte in a patient with alpha-1-antitrypsin deficiency with the genotype PiZZ. The lumina of the endoplasmic reticulum (ER) are dilated and contain aggregates of the unsecreted protein (stars). N, nucleus. M, mitochondrion ( $\times 30$ 000).

radiologically normal; the liver was clinically normal; the liver function tests were normal.

Serum AAT concentration was measured with a technique derived from Mancini's method (Martin, Vandeville, Martin, and Ropartz, 1974) in the patient and her parents. The Pi phenotype was determined according to Fagerhol and Laurell (1967) in the parents; the determination of Pi phenotype was not possible in the patient because of the absence of detectable AAT in the serum.

Liver biopsy was performed with a Menghini needle in the patient only. A fragment of the liver specimen was fixed in Bouin's fluid and embedded in paraffin; sections were stained with haematoxylineosin, Masson's trichrome and the PAS reaction after salivary digestion. Another fragment of the liver specimen was fixed in paraformaldehyde and was used for immunocytochemical studies; sections were incubated with anti-AAT antibodies labelled with peroxidase and observed on light and electron microscopy (Feldmann et al, 1974). Another fragment of the liver specimen was fixed in $1.5 \%$ osmium tetroxide solution buffered with veronal buffer, $\mathrm{pH}$ $7 \cdot 2$, for $90 \mathrm{~min}$ at $4^{\circ} \mathrm{C}$ and embedded in Epon; ultrathin sections were stained with uranyl acetate and lead citrate and were observed on electron microscopy.

\section{Results}

Serum AAT concentrations and Pi phenotypes of the patient and her parents are given in the table. The appearance of the liver on light microscopy was normal, except for vacuoles present in the cytoplasm of the hepatocytes; no PAS-positive globules were seen in the hepatocytes. No reaction with anti-AAT antibodies labelled with peroxidase was detected on either light or electron microscopy. The ultrastructural aspect of the hepatocytes was normal except for the presence of cytoplasmic vacuoles, 1-4 microns in diameter; these vacuoles, distinct from the endoplasmic reticulum and Golgi apparatus, were limited by a single membrane, and had the appearance of dilated lysosomes (fig 2). 


\begin{tabular}{lcl}
\hline & $\begin{array}{l}\text { Serum Alpha-1-antitrypsin } \\
(m g / 100 m l)^{1}\end{array}$ & Pi phenotype \\
\hline Patient & 0 & \\
Father & 74 & PiS \\
Mother & 126 & PiM \\
\hline
\end{tabular}

Table Serumalpha-1-antitrypsin concentration and $P i$ phenotype in the patient and her parents

${ }^{2}$ Normal: $240 \pm 100 \mathrm{mg} / 100 \mathrm{ml}$ (mean $\pm 2 \mathrm{SD}$ )

\section{Discussion}

That our patient had the genotype $\mathrm{Pi}_{-}$is based on the following arguments: (a) the serum AAT concentration of the patient was null; (b) the serum AAT concentration of both parents was lower than normal; (c) the parents' phenotypes were PiS and PiM, their genotypes being presumably PiS_ and PiM.. This patient represents the reported second case of homozygous genotype $\mathrm{Pi}$... The rarity of this genotype results from the 0.001 frequency of the allele $\mathrm{Pi}^{-}$(Laurell, Sveger, and Ljunggren, 1974).
Under the electron microscope, the endoplasmic reticulum of the hepatocytes appeared to be normal in our patient. This finding is compatible with the hypothesis that, in AAT deficiency with the genotype $\mathrm{Pi}_{\text {--, }}$ the mechanism for the null serum AAT concentration would be a defect in synthesis of this protein. An alternative hypothesis, likewise compatible with the normal ultrastructural aspect of the endoplasmic reticulum, is that, in this variant of AAT deficiency, an abnormal AAT is produced by the liver and secreted into the plasma but disappears rapidly from the plasma; the observation that after intravenous injection of normal AAT this protein disappeared from the plasma of a patient with the genotype $\mathrm{Pi}_{\text {_- }}$ at the same rate as from the plasma of normal subjects (Talamo et al, 1973) does not exclude this hypothesis.

Our patient was suffering from another hereditary disorder, mannosidosis. The coincidence of AAT deficiency with the genotype $\mathrm{Pi}_{\text {_- }}$ and mannosidosis, two rare, apparently unrelated hereditary diseases,

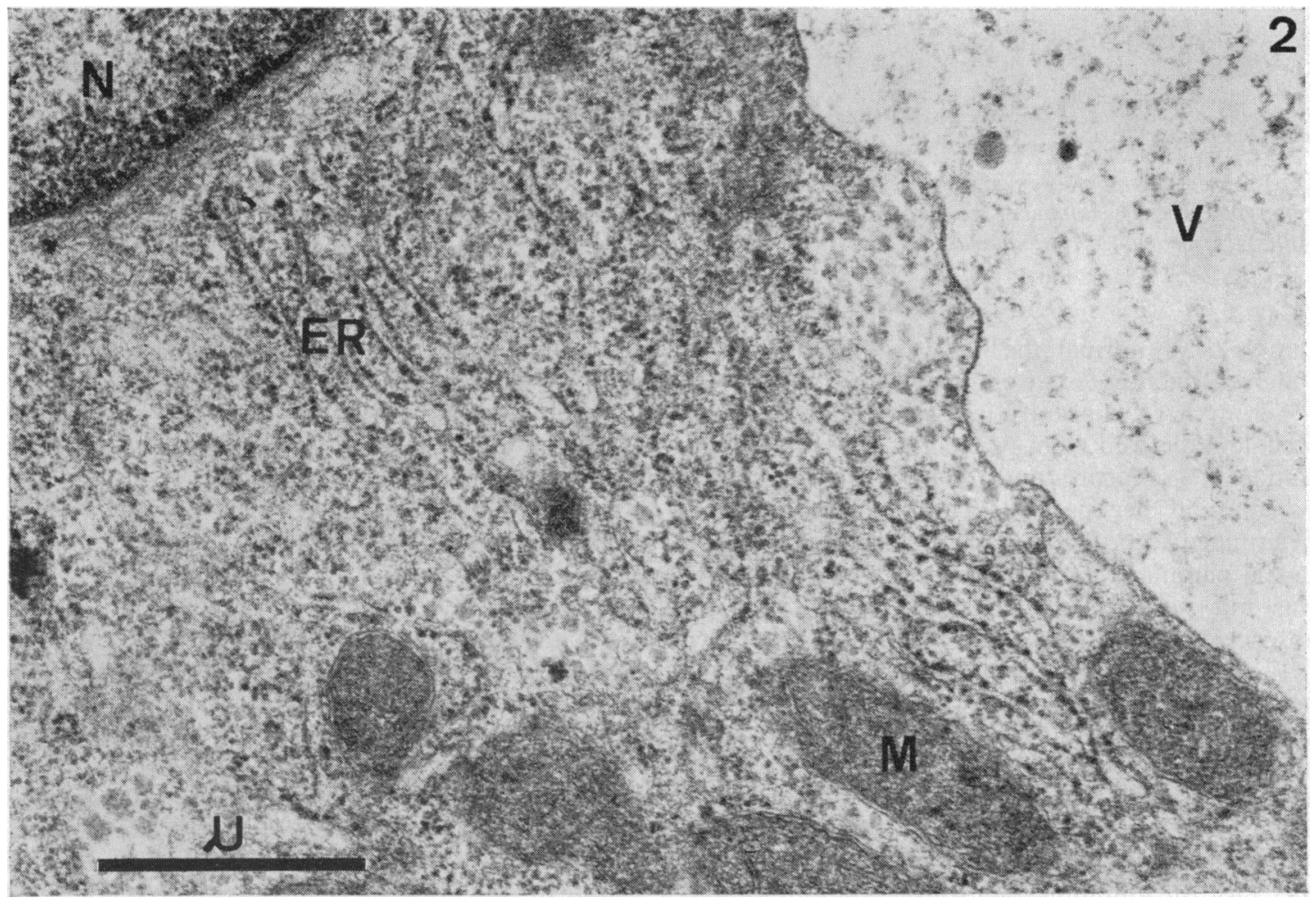

Fig 2 Electron microscope appearance of a part of a hepatocyte in the patient with alpha-1-antitrypsin deficiency with the genotype $P i_{-}$.. The endoplasmic reticulum $(\mathrm{ER})$ is normal. $A$ part of a cytoplasmic vacuole $(\mathrm{V})$ can be seen; this vacuole is related not to alpha-1-antitrypsin deficiency, but to mannosidosis, another hereditary disorder from which this patient was suffering (see text). N, nucleus. M, mitochondrion ( $\times 30000)$. 
is probably the consequence of consanguinity of our patient's parents. Mannosidosis is responsible for the vacuoles in the cytoplasm of the hepatocytes; these cytoplasmic vacuoles, in fact dilated lysosomes, are known to be present in the cytoplasm of various cells in patients with mannosidosis (Autio, Nordén, Öckerman, Riekkinen, Rapola, and Louhimo, 1973). The possibility that mannosidosis may affect the synthesis of AAT and/or the manifestations of AAT deficiency cannot be excluded; however, the enzyme and biochemical disorders described in mannosidosis (Autio et al, 1973) make this interference unlikely.

The authors are indebted to Professor C. Nezelof for performing the histological study and thank Mrs Jocelyne Guesnon for technical assistance. This work was supported by a grant from the Institut National de la Santé et de la Recherche Médicale (contract no. 7350484).

\section{References}

Autio, S., Nordén, N. E., Öckerman, P.-A., Riekkinen, P., Rapola J., and Louhimo, T. (1973). Mannosidosis: clinical, fine-structural and biochemical findings in three cases. Acta paediat. scand., 62, 555-565.

Eriksson, S., and Larsson, C. (1975). Purification and partial characterization of PAS-positive inclusion bodies from the liver in alpha ${ }_{1}$-antitrypsin deficiency. New Engl. J. Med., 292, 176-180.

Fagerhol, M. K., and Laurell, C. B. (1967). The polymorphism of 'prealbumins' and $a_{1}$-antitrypsin in human sera. Clin. chim. Acta, 16, 199-203.

Feldmann, G., Bignon, J., and Chahinian, P. (1974). The liver in $a_{1}$-antitrypsin deficiency. Digestion, 10, 162-174.

Feldmann, G., Bignon, J., Chahinian, P., Degott, C., and Benhamou, J. P. (1974). Hepatocyte ultrastructural changes in $a_{1}$-antitrypsin deficiency. Gastroenterology, 67, 1214-1224.

Laurell, C. B., Sveger, T., and Ljunggren, C. G. (1974). $a_{1}$-antitrypsin deficiency. Pi genotype ZO, SO and MO. Acta paediat. scand., 63,855-857.

Martin, J. P., Vandeville, D., Martin, C., and Ropartz, C. (1974). Identification des phénotypes du système $\mathrm{Pi}$ et comparaison des méthodes de dépistage des déficits en alpha-1-antitrypsine. Ann. Biol. clin., 32, 197-207.

Perelman, R., Nathanson, M., Lepastier, G., Lesavre, P., Plainfosse, B., Chirazi, S., and Seringe, P. (1975). Mannosidose associée à l'absence d'alpha-1-antitrypsine. Présentation d'une observation. Revue de la littérature. Ann. Pediat., 22, 385-396.

Schultze, H. E., Heide, K., and Haupt, H. (1962). $a_{1}$-Antitrypsin aus Humanserum. Klin. Wschr., 40, 427-429.

Schultze, H. E., and Heremans, J. F. (1966). Molecular Biology of Human Proteins with Special Reference to Plasma Proteins, Vol. 1, p. 365. Elsevier, Amsterdam.

Talamo, R. C., Langley, C. E., Reed, C. E., and Makino, S. (1973). $a_{1}$-antitrypsin deficiency: a variant with no detectable $a_{1}$-antitrypsin. Science, 181, 70-71. 